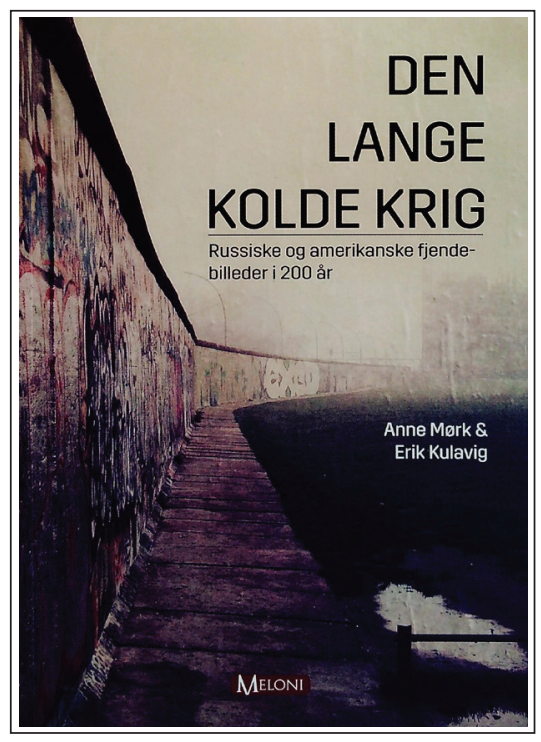

\section{Den lange kolde krig: Russiske og amerikanske fjendebilleder i 200 år}

\author{
Anne Mørk \& Erik Kulavig \\ Danmark: Forlaget Meloni 2020 \\ 144 sidor. ISBN 9788771501223
}

Recenserad av Kristian Gerner [professor
emeritus i historia, Lunds universitet,
Kristian.Gerner@hist.lu.se]

Amerikaexperten Anne Mørk och Rysslandsexperten Erik Kulavig vid Syddansk Universitet hävdar att det kalla kriget mellan USA och Ryssland inte upphörde definitivt med rivningen av Berlinmuren 1989. Det återupplivades efter ett decenniums romans mellan parterna och pågår än idag. De två författarna visar att det tog sin början redan 1917 och att de amerikanska fiendebilderna hade sina rötter i 1800-talets motsatsförhållande mellan det demokratiska USA och det ryska självhärskardömet. Fiendebilderna under 1900-talet bottnade i rivaliteten mellan två missionsprojekt med globala ambitioner, det kapitalistiska amerikanska och det socialistiska ryska.

Mørk och Kulavig framhåller att motsättningen mellan den nordamerikanska och den eurasiatiska stormakten har varit både geopolitisk och ideologisk. Vi nordbor har varit inneslutna i den amerikanska politiska, ideologiska och kulturella hegemonin i över hundra år. Mørks 30 sidor om "Rusland set fra USA» är helt enkelt en koncis sammanfattning av för nordiska läsare välbekant historiskt stoff $i$ lika välbekant USA-kritisk tappning. Kulavigs 50 sidor "USA set fra Rusland» är en lysande sammanfattning av Sovjetunionens historia med perspektiv från dagens forskningshorisont och från den ryska kulturens källsprång i ortodoxi och kollektivism. Han ger människor utanför sovjetforskarnas krets ny kunskap.

Asymmetrin i allmänna kunskaper om USA och Ryssland i Norden visar sig i att Mørk demonstrerar att hon väl känner sitt USA men vet föga om Kulavigs Ryssland. Hon internaliserar det om Ryssland föga kunniga amerikanska perspektivet. Det är anmärkningsvärt att ta del av hennes beskrivning av Pragvåren 1968, det vill säga av 
de reformistiskt sinnade tjeckoslovakiska kommunisternas strävan att skapa en "socialism med mänskligt ansikte». Mørk skriver att det var »et anti-kommunistisk oprør» och att USA inte gav något verkligt stöd till »det tjeckoslovakiske oprør» (s. 29).

USA-skildringen i Den lange kolde krig tjänar som fond för analysen av Sovjetunionen och Ryssland. Det vi kallar det kalla kriget handlar om Rysslands roll i världspolitiken. USA var och är en fortsättning på den västeuropeiska imperialismen. Ryssland är anomalin. Detta land har varit en del av den västeuropeiska imperialismen men samtidigt ett objekt för dess kulturella expansiva kraft. Iver Neumann kallade en gång Ryssland för Västeuropas eviga lärjunge. Detta perspektiv genomsyrar Erik Kulavigs analys: de ryska bilderna av USA var inte bara av fienden utan också av läromästaren.

"Rusland set fra USA» handlar om bilden av det främmande, det som är utanför. Ryssland var en skräckbild för USA, särskilt när landet hette Sovjetunionen. »USA set fra Rusland» handlar om rysk självförståelse och rysk mindervärdeskänsla. USA var en måttstock för Ryssland. Kulavig påminner om att Sovjetunionens ledare Nikita Chrusjtjov förkunnade att hans land skulle gå ikapp och förbi USA. USA:s presidenter Eisenhower och Kennedy hade inte Sovjetunionen som måttstock, även om utmaningen genom uppskjutandet av de sovjetiska Sputnik-satelliterna 1957 ansågs behöva mötas med bättre utbildning och forskning i USA.

Erik Kulavig visar att USA under det kalla kriget genom sin mjuka makt i skepnad av konsumtionssamhället och populärkulturen påverkade människorna i Sovjetunionen. Han visar också att Sovjetunionen/Ryssland förvisso hade en självständig livskraftig kultur. Men medan den amerikanska populärkulturen under efterkrigstiden var känd och anammad i hela världen var den likartade sovjetiska varianten i stort sett okänd bland folk i allmänhet i USA och i Norden. Bob Dylan hade en rysk motsvarighet i Vladimir Vysotskij. Kulavig citerar en sovjetisk kommissarie som sade attVysotskijs sånger var lika farliga för sovjetmakten som kulorna från en Kalasjnikov. De amerikanska ledarna upplevde knappast Bob Dylan som ett motsvarande hot.

Anne Mørk påvisar att det under trettiotalet fanns intellektuella i USA som såg Sovjetunionen som ideal och ett framtidsland. Men hon visar också att uppfattningen bottnade i okunskap om de verkliga förhållandena i Sovjetunionen. Erik Kulavig lyfter fram den grundläggande skillnaden i synen på framtiden i de två länderna. Amerikanerna var utopister. Ryssarna var realister. Det handlade dessutom om helt skilda aktörskategorier, maktlösa respektive mäktiga. I USA var det fråga om en marginell minoritets drömbild. I Sovjetunionen gällde det makthavarnas syn på hur man faktiskt skulle bygga framtidssamhället.

Erik Kulavig klargör att den sovjetiska statens grundare Vladimir Lenin var ett lysande exempel på den anda som vägledde ryska härskare från Peter den store i början av 1700-talet till Dmitrij Medvedev trehundra år senare, nämligen att Ryssland måste moderniseras. Motpolen USA har uppfattat sig själv som det moderna projektets essens. Detta anger hur djupt asymmetriskt det kalla kriget mellan USA och Sovjetunionen var. Den förra var det moderna i sig. Den andra ville bli modernt. 
Kulavig återger ett välbekant slagord från Lenin, en devis som prydde ett elverk i Moskva: "Socialismen är lika med sovjetmakt och elektrifiering av hela landet.» Han konstaterar att citatet är stympat. Lenin fortsatte med att tala om "tysk arbetsetik» och "amerikansk företagaranda» som nödvändiga faktorer för byggandet av det socialistiska samhället. Men Lenin skrämde bort kapitalisterna i USA därför att han på samma gång som han hyllade entreprenörerna där talade om att störta kapitalismen och lät förstatliga utländska företag. Motsättningen mellan att använda kapitalistiska medel och tillåta västliga investeringar i bygget av det socialistiska samhället å ena sidan, och att hålla fast vid den statsstyrda kommandoekonomin enligt gammalt ryskt mönster å andra sidan, präglade Sovjetunionen till slutet.

Den lange kolde krig har som bilagor 45 sidor amerikanska och ryska historiska dokument, från en ledare om "Ryssands återfödelse» i New York Times 16 mars 1917 till en (översatt) ordagrann återgivelse av Putins och Trumps presskonferens $i$ Helsingfors 16 juli 2018. Putin talade som en cynisk statsman. Trump orerade fritt.

Det mest tänkvärda dokumentet är Alexander Jakovlevs instruktion 21 januari 1971 om hur Sovjetunionen i fora för den internationella publiken skulle uppmärksamma mörka årsdagar i USA:s rasistiska historia och därigenom underminera USA. Det är samma Jakovlev som 15 år senare skulle införa glasnost, låta uppmärksamma alla de svarta fläckarna i Sovjetunionens historia och underminera landet.

Anne Mørk presenterar amerikanska fiendebilder av Ryssland. Erik Kulavig berättar om relationen till USA som en del av Rysslands moderna historia. 